\title{
Trade, Education Externalities and Economic Growth: Evidence from Nigeria
}

\author{
Taiwo Owoeye ${ }^{1}$, Dayo Benedict Olanipekun ${ }^{2}$ \\ ${ }^{I}$ Department of Economics, Ekiti State University, Nigeria \\ ${ }^{2}$ Department of Economics, Ekiti State University, Nigeria
}

\begin{abstract}
An open economy requires a well-educated workforce to drive economic growth through technology transfer and spill overs. This paper investigates the impact of trade openness and human capital on economic growth for Nigeria using annual data for 1980-2015. The growth rate of per capita income is used as dependent variable while the sum of total imports and total exports as a fraction of GDP and gross secondary school enrollments were used as explanatory variables, inflation rates and exchange rates were also included as control variables. Using ARDL estimation technique the study finds that trade openness impact negatively and significantly on expansion of output per worker, and this may be attributed to the fact that Nigeria exports mainly primary products with no value-added. Also, human capital has insignificant impact on economic growth, and this may be because low quality schooling is incapable of producing human capital. A depreciating exchange rate and a low inflation rate expand output per worker according to the results while domestic investment returns a negative coefficient contrary to expectation. This study therefore shows that policy makers need to do two things to derive positive education externalities on economic growth through trade openness. One, they should improve the quality of education so that schooling can produce human capital. Two, diversify Nigerian exports to value-added goods and services so that trade openness can help in technology transfer and innovation diffusion.
\end{abstract}

Keywords: economic growth, human capital, trade openness, technology diffusion

\section{Introduction}

For most developing countries one of the best ways to generate high economic growth is to integrate into global economy and this is done through trade. Trade integration is therefore an important driver of economic growth. Openness to trade has been shown to produce the possibility of an international product cycle, as the production of certain products previously produced by high income countries are shifted to low-income countries (Busse and Kroniger, 2012). This process has been shown to lead to diffusion of technology and innovation from developed countries to developing countries. This makes new technology available in developing countries and spread the frontier of new technology to developing countries. It also helps developing countries to adapt new technology and innovations to local conditions. However the most important driver of technological adoption and diffusion is the level of human capital development in the developing country(Benhabib and Spiegel,2004).

For a developing country to be integrated into the global economy therefore there is the need to have a well-educated labour force that can adapt to changing times and conditions. Traditional trade theory predicts welfare gains from trade through specialisation, innovation and invention, improvement in productivity level and optimal resource allocation. However the ability of any developing country to have these trade benefits depends in how educated and well trained the labour forces are. For most sub-Saharan African countries trade liberalisation has not been beneficial because it has not benefited the poor (Goff and Sigh, 2014). Most subSaharan African countries have, since they adopted the World Bank supported structural adjustment programme in 1980s, significantly liberalised their economy. However, the large welfare gains expected from the opening up of their economies have not materialised partly because low-income countries have not be able to access the lucrative markets in developed countries especially in markets for labour intensive consumer goods.

There are different reasons why trade liberalisation has not benefited the poor in Africa, and this includes, the pattern of the trade as most Africa countries export primary products, poor financial system, unfair trade rules, poor infrastructure, and high cost of production among others(see Fosu, 1990a,1990b). However, an important reason may be the low human capital development in most African countries. Nigeria, African largest economy and most populated country, represents a good example of how trade liberalisation has neither benefitted the poor nor improves the economy over a long period. Nigeria adopted the Structural Adjustment Programme in 1986 effectively liberalising its economy and implementing a wide range of policy reforms which opened up the economy, reduce government participation in some key sectors like banking and increase private sector participation. However the results have not been encouraging, economic growth stagnated during the 1980s and 1990s and only picked at the turn of the century due to increase in oil price, Nigerian main export 
earnings. During the period 2000-2014, Nigerian economy grew at an annual average of 6 per cent before the slumps in oil price crashed this spectacular growth rates in 2015 to around 3 per cent and then the economy contracted in 2016. Despite the fact that the Nigerian economy grew by 6.8 per cent in 2014 the high population growth rate makes it difficult for per capita income to increase substantially. It stood at USD2, 980 in 2013 and put Nigeria at $131^{\text {st }}$ position in the world (World Bank, 2015). Also poverty rate in Nigeria increased from 54.4 per cent in 2004 to 69 per cent in 2010 according to figures from the Nigerian National Bureau of Statistics

A major feature of the Nigerian economy is its monoculture nature; it depends on crude oil exports for 90 per cent of its foreign earnings and 70 per cent of government revenue, whereas the structure of the Nigerian economy is changing and becoming more diversified, the structure of itsinternational trade remains stubbornly undiversified. As at 2014, agricultural sector contribution to Gross Domestic Products (GDP) has declined to 20 per cent from 24 per cent in 2010. In the same vein oil and gas which dominates export earnings also has its share of GDP declining from 15.5 per cent in 2010 to 11 per cent in 2014. Wholesale and retail also improved from 17 per cent in 2010 to 18.6 per cent 2014 , just as manufacturing sector also increased its share of GDP from 6.6 per cent in 2010 to about 10 per cent in 2014. Other sectors like telecommunications and entertainments have improved their contributions to national output (CBN, 2015). What these figures have shown is that Nigerian economy is becoming increasingly diversified. However, Nigerian external sector is still dominated by crude oil exports and trade indicators are still vulnerable to fluctuating oil price. An analysis of the components of Nigeria current account as a percentage of GDP between 2007 and 2014 shows that trade balance which was 14.2 per cent of GDP in 2007 declined to 3.7 per cent in 2014 mainly due to falling oil price and the inability of the policy makers to explore other sources of foreign earnings. For this same reason the share of export in GDP also declined from 25 per cent in 2007 to 14.5 per cent in 2014, while current account balance which stood at 10.2 per cent in 2007 declined to 0.2 per cent in 2014 (CBN, 2014). The above shows the level of vulnerability of Nigerian external sector and this trend is also supported by 15.6 per cent drop in foreign reserves from USD 34.52billion in December, 2014 to USD 29.1billion in December, 2015 (ADB, 2015).

An important channel through which Nigeria can benefit from trade openness and diversify its export base is to develop a well-educated workforce. Thecore objective of this paper therefore is to investigate how education human capital has affected the trade- economic growth nexus in Nigeria. Most of the studies that have investigated the effect of education of trade- growth nexus were cross-country studies with limited space for country specific effects.

The remainder of this paper is organised as follows: Section two presents the conceptual and empirical reviews. Section three outlines the methods, and the models. Section four discusses the results, while section five concludes.

\section{Conceptual And Theoretical Framework: Trade, Technological Diffusion And Education Externalities}

The literature on how trade drives growth and diffuses technology and innovation is rich and diverse. The main concerned of the literature is that the question of whether trade is good for economic growth or not depends on the transmission channels. The transmission channels for the trade-growth nexus are expanding very fast. Initial trade theories place emphasis on comparative advantage as the core of transmission channels. However, new trends are emerging that stress free movement of factors, technology diffusion and Global Value Chain (GVC). These new channels have been identified as the offshoot of dynamic trade theory which focuses on accumulation of human capital, derived from investment in education and technological diffusion in one hand, and physical capital derived from higher saving rate and investment on the other hand (Nowak-Lehman, 2000). The human capital nexus can also be extended to improvement in managerial and organisational skills.

The theoretical foundation of the link between trade-growth nexus and human capital accumulation is traceable to the emergence of the endogenous growth theory in the 1980s. The standard neoclassical growth theory developed by Solow, (1956) has predicted the convergence of economic growth rates between rich and poor countries. The model also showed that long run improvement in standard of living is driven by exogenous technological changes (Solow, 1956). The basic weakness of the neoclassical model is it inability to explain why convergence does not take place across different regions. In other words why it is that growth rates of rich and poor countries do not converge across different regions since the Solow model predicts that convergence will be unconditional. It was the need to explain growing income gap between rich and poor countries that gave rise to the conditional convergence approach (see, Barro, 1991, Sala-i-Martins, 1994). Under this approach convergence will only occur when there is a variable within the growth process with properties of increasing return, and knowledge embedded in human capital possesses such properties. Convergence only occurs therefore when an economy can develop activities with increasing return to scale tendencies, and this can only be found in technological progress and the ability of the stock of human capital within the economy to keep on adapting to changing conditions. It is therefore the human capital stock that raises the rate of technological innovation in rich countries and also increases the ability of poor countries to adopt, imitate and absorb new 
technologies from abroad. A key channel of doing this is international trade. The inability of the neoclassical growth model to explain technological progress within the growth process gave rise to the new endogenous model

A second reason for the emergence of the endogenous model was the impressive performance of the Asian Tigers since 1970s and the need to find a model to fit these growth miracles. It was this need that spurned the endogenous growth theory (Romer, 1986:1990, Lucas, 1988). This theory was later expanded to show how technological progress and innovation spur long-run economic growth (Grossman and Helpman, 1991: Dollar, 1992). The driver of this channel has been identified as investment in human capital (Lucas, 1988) and investment in physical capital, (Romer, 1990). Unlike, the standard Solow model, the AK model describe a situation where there is no diminish return to capital because improvement in stock of knowledge by individual worker more than offset depreciation in capital. The positive externalities that are attributed to investment in education can be trade-induced or can be driven by trade policies both through technological transfer and spillover from abroad and innovation at home. The first will come from technology embodied in machine and training. The second willcome in the later stage as the economic matures and adapts foreign technology to domestic conditions. The channel of transmission in both cases is international trade because it facilitates access to modern technology from developed countries to developing countries through the transfer of technology and spill-overs. This has two effects one, it promotes technical progress and two; it increases the rate of growth of national output. In the long-run the exposure of the domestic economy to these new technologies creates competitive firms who can now access bigger markets. More importantly as these firms compete in the global market the rate of innovation in the economy increases, more investment will be made in R\&D and productivity will improve through learning-by-doing and technological spill over will occur exponentially. Trade is therefore crucial to achieving productivity convergence between rich and poor countries and the driver of that convergence is an educated workforce. It also helps in re-allocation of resources used in R\&D to avoid redundancy of resources (Romer, 1990), trade also helps in creating stronger bonds among trading partners, especially those in the same trading blocs or economic unions.

Also the non-rival property of knowledge means that technology diffusion can take place across different trading partners through their stock of educated workforce. This process will generate increasing returns to knowledge through education externalities. A key requirement for these benefits of trade to occur is an educated labour force.

\subsection{Empirical Literature}

The literature on the trade-growth nexus has been ambiguous showing no definite relationship between trade and economic across different regions of the world. In some respect trade has been shown to drive economic growth by lowering international barriers and reducing transaction cost among trading partners. In other respect trade has also exposed developing countries to some form of unhealthy competitions and drive resource rich countries into perpetual poverty as they are unableto expand to tradable sectors.

For specific studies, (Edward, 1997:Harrison, 1994), have shown that contrary to what trade theories suggest labour in the real world may not be very mobile because of some institutional barriers to firm entry and exist mostly in developing countries. The study suggests that to have a better understanding of how trade drives economic growth there is the need to consider the level of factor mobility between regions more than within region. For some developing countries trade openness may also expand the size of the informal sector as firms reduce their workforce due to competitions, unemployed workers will populate the low productivity informal sector. According to Attansioet al (2004), there is a higher chance of been unemployed in the traded good sectors than the non-traded goods sector in Colombia. This is an indication that for most developing countries trade benefit may be exclusive when it does not expand the traded-goods sector. Trade may also drive up the skill intensity of the economy in such a way that it will negatively affect low-skill workers especially before the economy can adjust to a new skill intensity equilibrium.(Winter et al, 2004 ). For most resource-rich countries trade openness may stimulate the expansion of the primary sector and contracts the tradable sectors. This has been the experience of most resource- richAfrican countries (Collier and Bates, 2007).

However, the trade-economic growth nexus has been shown to be sensitive to model specifications and the proxies used. Busse and Koniger (2012) argued that when the values of volume of export and import as a share of lagged total GDP are used for trade openness, a positive and highly significant impact of trade on economic growth was established for a large group of countries at different levels of development. Also, Sach and Warner, (1995) find a positive relationship between trade and economic growth in a cross-country studies but show that this relationship is also driven by extensive policy reforms. Some studies have also investigated how policy drives the benefits of trade. Goff and Sigh (2014) showed how trade openness became beneficial in sub-Saharan African where education attainment is higher. The study shows that a more educated population proxy by primary school completion rate would be more able to acquire new skill sought by growing sectors and adjust more rapidly to new conditions of labour market. The intuition here is that it is when a large stock of 
educated workforce exist that trade can change the pattern of exports from primary products to tradable goods provided other institutional reforms like good governance and rule of law are also in place. Also Banerjee and Roy, (2014) investigated the relationship between human capital, technological progress in India. The study used the autoregressive distributed lag (ARDL)- based co- integration techniques and the results indicated that the technology progress, human capital and trade are good determinants of economic growth in India. The most significant of these variables is human capital.

For Africa regional economic group, Chen and Gupta (2006) investigated the effect of international trade on economic growth for SADC region in Africa for the period of 1900 to 2003 . The findings showed that trade openness measured by the ratio of sum of total imports and total export to GDP has a significant positive impact on economic growth. For Nigeria, Arodoye and Iyoha,(2014), Obadan and Elizabeth (2010) confirmed a positive relationship between trade openness and economic growth. Also, Egwaikhide, (1994) found that total export impacted positively on economic growth for the period spanning 1959 to 1989. However, Ekpo, (1995) found that the traditional trade openness measures as, total trade/GDP did reduce output growth for the period of 1970-1992. The study used the aggregate production function and also established a positive relationship between capital stock, labour force and economic growth. A unique nature of the study is the use of black market exchange rate premium as a measure of trade share, and the negative impact this variable has with economic growth.

Other studies, Ekpo and Egwaikhide, (1994), Olomola,(1998) using the convectional measure of trade openness found negative relationship with output growth.Akinlo,(2003) also investigated the effect of FDI on the expansion of output in Sub-Saharan African countries. The study found that FDI has a positive impact on economic growth and this impact is significant. The study, because of its cross-sectional nature ignores the country specific effects

\section{Theoretical Model And Econometric Specifications}

The Solow growth model (1956) is traditionally the first step in the analysis of sources of long-run growth in output. The model identifies savings rate, population and exogenous technological progress as the main drivers of evolution of capital accumulation and by extension growth in output per capita. However, the augmented version of the model has expanded the original model and fit it into a real world setting.

Specifically, Mankiw, Romer, and Weil,(1992) provided an augmented version of the neoclassical model and extended the determinants of growth in output per capita to include many variables, like level of technology $\left(A_{t}\right)$, the rate of technological progress $(g)$, the initial output per worker $\left(y_{0}\right)$, the savings $\operatorname{rate}\left(s_{k}\right)$, the share of capital/human capital in output $(\alpha) /(\beta)$, the rate of convergence to the steady state, the depreciation $\operatorname{rate}(\delta)$, growth rate of the labour force $(n)$, and the investment in human capital $\left(s_{h}\right)$.

$\ln y_{t}-\ln y_{o}=-\left(1-e^{-\Lambda t}\right) \ln y_{o}+\left(1-e^{-\Lambda t}\right) \ln A_{t}+\left(1-e^{-\Lambda t}\right) \frac{\alpha}{1-\alpha-\beta} \ln s_{k}+\left(1-e^{-\Lambda t}\right) \frac{\beta}{1-\alpha-\beta} \ln s_{h}-$ $\left(1-e^{-\kappa t}\right) \frac{\alpha+\beta}{1-\alpha-\beta} \ln (n+g+\delta)$

The model also assumes that the level of technology at a given point in time depends on the country initial level of technology $\left(A_{0}\right)$ while the growth rate of technology is constant across all countries. This help to explain how technology helps in explaining differences in output per capita across countries.

$A_{t}=A_{0} e^{g t}$

For developing countries the assumption of constant growth rate of technology seems unrealistic.

In our initial theoretical review we have shown that one of the channels through which international trade drives economic growth is how it helps in diffusion of internationally available technology and that this depends on country specific factors. Trade in goods and services across borders are a principal channel for the international exchange of ideas. Trade is an important determinant of the difference in the diffusion of technology. There is the need therefore to incorporate trade as a country-specific determinant of technology level $\left(A_{i t}\right)$

$A_{i t}=A_{0} e^{g t} e^{\emptyset_{j} X_{i j}}$

From the above, we now incorporate some of the properties of the augmented model of Mankiw et al, (1992) with more realistic assumption about the country-specific development of the technology level. Following, Busse and Kroniger (2012), the model above yields a testable specification of a regression equation...

$\ln y_{i t}=\alpha+\left(\beta_{1}+1\right) \ln y_{i t-1}+\beta_{2} \ln s_{k, i t}+\beta_{3} \ln s_{h, i t}+\beta_{4} \ln \left(n_{i t}+g+\delta\right)+\emptyset_{j} X_{j, i t}+\tau_{t}+\eta_{i}$

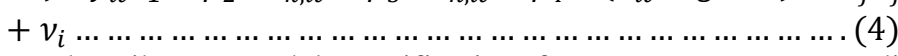

Equation (4) above describes a model specification for a cross-country studies wherei represent different countries and t, represents time period. However since this study deals with a single country we can then reformulate equation (4) to include trade and human capital variables and other control variables to give equation (5)

$\mathrm{PCAP}=\alpha_{0}+\alpha_{1} G C F G+\alpha_{3}$ TRDOP $+\alpha_{3} I N F+\alpha_{4} R E E F+\alpha_{5}$ SECEN $+\varepsilon_{t} \ldots \ldots \ldots$ (5)

where; 
$\mathrm{PCAP}=$ growth rate of per capita income

$G C F G=$ the share of domestic investment in GDP.

$T R D O P=$ the sum of total imports and total exports as share of GDP

$I N F=$ rate of inflation

$R E E R=$ foreign exchange rate

SECEN $=$ gross secondary enrolment.

The coefficients of investment, trade openness, and secondary enrollments are expected to be positive, while those of inflation and exchange rates are expected to be negative.

\subsection{Variables and Data Sources.}

Per Capita Income: The dependent variable is the growth GDP per capita, and the reason for choosing this proxy is because per capita income reflect more the growth potential of a country than GDP since it is divided by population. As shown by the neo-classical growth model it is better to analyse the contribution of individual workers to the growth process irrespective of the size of the economy.

Trade Openness: Two different categories of trade openness have been identified in the literature

Incidence- base measures and outcome based measures. The first deals with tariff data and trade policy while the second deals with trade data. This study follows the convection in the literature and adopts the outcomebased approach. It three measures of trade are imports plus exports as a fraction of GDP, and total imports and total exports separately also as fractions of GDP. This study uses only the sum of total imports and total exports as share of GDP.

\section{Education}

The stock of human capital in any economy is the driver of technological adoption through international trade. The challenge in the literature is the identification of the appropriate proxy for human capital. The three basic proxies are expenditure on education, which is considered as input in the education process, enrolment, which is considered as flow and attainment which is considered as stock (Solow, 2003). Other measures of human capital are literacy rates, average year of school of the population aged 15 years and above, relative scores in international test in both numeracy and fluency. New measures of technology-induced human capital stock are the numbers of patents and copyright and the ratios of engineers and scientists among university graduates.However for most African countries availability of some of the above measures of human capital limit their usage. Among all these measures the two most available are expenditures on education and education enrolments, but both of them are not as reliable are education attainment which is the stock of human capital in the economy. This study therefore uses gross secondary school enrolment as the measure of education in our model for Nigeria. It is expected to have positive impact on the growth of output per capita.

\section{Investment}

This is measures by the ratio of Gross Capital Formation in Gross Domestic Product. It is the standard measure of investment and it is superior to the usage of only Gross Capital Formation because it reflects the relative size of investment in GDP it is expected to have a positive relationship with output per capita.

Inflation Rate: This is proxy by the real rate of inflation and it is expected to have a positive relationship with per capita income

Real Exchange Rate: This is the exchange rate of the domestic currency, the naira, to USD. It is expected to have a negative relationship with growth rate of output per capita.

Also all the data for this study were sourced from World Development Indicators as published by the World Bank.

\subsection{RESULTS}

\section{Results And Discussions}

The Augmented Dickey-Fuller approach to test for unit root was adopted in this study. All variables were tested at level and first difference. The result shows that per-capita income (GDP_PCAP), gross fixed capital formation (GCF_G) and inflation (INF) are stationary at level. However, other variables, such as real effective exchange rate (REER), secondary school enrolment (SEC_ENRR) and trade openness (TRD_O) are stationary after first difference. Hence, the appropriate procedure to be used for the analysis is the autoregressive distributed lags (ARDL). The ARDL enables the analysis of variables at level and first difference forms. 
Table 1: Augmented Dickey-Fuller Unit Root Test

\begin{tabular}{|l|l|l|l|l|l|}
\hline Series & Level Constant & Critical Value at 5\% & $\begin{array}{l}\text { First Diff. } \\
\text { Constant }\end{array}$ & $\begin{array}{l}\text { Critical Value at } \\
\mathbf{5} \%\end{array}$ & Decisions \\
\hline GDP_PCAP & -4.824558 & -2.951125 & -6.540465 & -2.957110 & \\
\hline GCF_G & -3.316827 & -2.957110 & -5.030075 & -2.960411 & $\mathrm{I}(0)$ \\
\hline INF & -5.639522 & -2.951125 & -7.008709 & -2.957110 & $\mathrm{I}(0)$ \\
\hline REER & -2.796316 & -2.954021 & -4.379631 & -2.957110 & $\mathrm{I}(0)$ \\
\hline SEC_ENRR & 0.255239 & -2.951125 & -5.892358 & -2.954021 & $\mathrm{I}(1)$ \\
\hline TRD_O & -1.924171 & -2.951125 & -8.004205 & -2.954021 & $\mathrm{I}(1)$ \\
\hline
\end{tabular}

\section{Cointegration Test and Error Correction Model Results}

The ARDL result is presented in table 2. Evidence from the result obtained show that inflation (INF) and trade openness (TRD_O) are statistically significant at $10 \%$ level. Further, a period lag real effective exchange rate is statistically significant at 5\%. Other variables employed in the analysis, namely, gross fixed capital formation (GCF_G and secondary school enrollment are not statistically significant at conventional levels. The negative coefficient of inflation suggests that a percentage increase in inflation would reduce percapita income by $0.1 \%$. Exchange rate depreciation would result to increase in per-capita income (see table 2 ). Contrary to expectation, trade openness had a negative effect on per-capita income.

Dependent Variable: GDP_PCAP

Table 2: ARDL

Number of models evalulated: 3072

Selected Model: ARDL(1, 1, 0, 1, 1,1)

Sample (adjusted): 19822015

Included observations: 34 after adjustments

\begin{tabular}{|l|l|l|l|l|}
\hline Variable & Coefficient & Std. Error & t-Statistic & Prob. $^{*}$ \\
\hline GDP_PCAP(-1) & -0.028762 & 0.164859 & -0.174467 & 0.8630 \\
\hline GCF_G & 0.308486 & 0.484590 & 0.636593 & 0.5307 \\
\hline GCF_G(-1) & -0.765568 & 0.461778 & -1.657870 & 0.1109 \\
\hline INF & -0.100744 & 0.051001 & -1.975339 & 0.0603 \\
\hline REER & 0.016010 & 0.017687 & 0.905207 & 0.3747 \\
\hline REER(-1) & -0.037897 & 0.017752 & -2.134777 & 0.0437 \\
\hline SEC_ENRR & 0.299736 & 0.186304 & 1.608859 & 0.1213 \\
\hline SEC_ENRR(-1) & -0.374887 & 0.259766 & -1.443175 & 0.1625 \\
\hline TRD_O & -0.234320 & 0.119069 & -1.967938 & 0.0612 \\
\hline TRD_O(-1) & 0.139618 & 0.101520 & 1.375280 & 0.1823 \\
\hline C & 19.78226 & 13.94567 & 1.418523 & 0.1694 \\
\hline
\end{tabular}

Table 3 presents the result of the long-run bound test. The computed F-statistic is compared with the various bounds, namely lower and upper bound of the Pesaran table. Empirical finding from the result obtained show a strong evidence of long-run relationship among the variables employed in the study.

Table 3: ARDL Bounds Test

Date: 05/22/17 Time: 21:45

Sample: 19822015

Included observations: 34

Null Hypothesis: No long-run relationships exist

\begin{tabular}{lll}
\hline \hline Test Statistic & Value & $\mathrm{K}$ \\
\hline \hline F-statistic & 7.235857 & 5 \\
\hline \hline
\end{tabular}

Critical Value Bounds

\begin{tabular}{lll}
\hline \hline Significance & IO Bound & I1 Bound \\
\hline \hline $10 \%$ & 2.26 & 3.35 \\
$5 \%$ & 2.62 & 3.79 \\
$2.5 \%$ & 2.96 & 4.18 \\
$1 \%$ & 3.41 & 4.68 \\
\hline \hline
\end{tabular}

The short-run dynamic relationship is presented in table 4. The error correction model coefficient is significant and of the right sign. The result indicates a high speed of convergence to long-run after a short-run. In the estimates, inflation and trade openness are statistically significant at $10 \%$ level. Other variables in the estimation are not significant. 
Trade, Education Externalities And Economic Growth: Evidence From Nigeria

Table 4: Short-Run Error Correction Model

\begin{tabular}{|l|l|l|l|l|}
\hline Variable & Coefficient & Std. Error & t-Statistic & Prob.* \\
\hline D $($ GCF_G $)$ & 0.308486 & 0.484590 & 0.636593 & 0.5307 \\
\hline D(INF) & -0.100744 & 0.051001 & -1.975339 & 0.0603 \\
\hline D(REER) & 0.016010 & 0.017687 & 0.905207 & 0.3747 \\
\hline D(SEC_ENRR) & 0.299736 & 0.186304 & 1.608859 & 0.1213 \\
\hline D(TRD_O) & -0.234320 & 0.119069 & -1.967938 & 0.0612 \\
\hline CointEq(-1) & -1.028762 & 0.164859 & -6.240255 & 0.0000 \\
\hline
\end{tabular}

The long-run coefficients are presented in table 5. In the results, gross fixed capital formation and inflation are statistically significant in the long run. The coefficient shows that a percentage increase in gross fixed capital formation would reduce per-capita income by $0.4 \%$. Similarly, increase in inflation is detrimental to per-capita income. One percent increase inflation would result to $0.1 \%$ decline in per-capita income.

Table 5: Long Run Coefficients

\begin{tabular}{|l|l|l|l|l|}
\hline Variable & Coefficient & Std. Error & t-Statistic & Prob.* $^{*}$ \\
\hline GCF_G & -0.444302 & 0.243171 & -1.827119 & 0.0807 \\
\hline INF & -0.097928 & 0.051083 & -1.917023 & 0.0677 \\
\hline REER & -0.021275 & 0.013646 & -1.559034 & 0.1326 \\
\hline SEC_ENRR & -0.073050 & 0.160708 & -0.454552 & 0.6537 \\
\hline TRD_O & -0.092054 & 0.130330 & -0.706316 & 0.4871 \\
\hline C & 19.229177 & 13.788584 & 1.394572 & 0.1765 \\
\hline
\end{tabular}

\subsection{Discussions}

The main aim of this paper is to investigate how trade openness working through technology transfer improves the rate of economic growth. The basic idea is that a well-educated labour force will provide positive externalities for economic growth throughexpansion in output per worker. The expectation therefore is that the proxies for education and trade openness should impact economic growth positively and significantly. However, the result showed that trade openness has a negative impact on output per capita. This may be as a result of the fact that the nature of tradein Nigeria like most developing countries is dominated by export of primary products. Specifically in Nigeria, crude oil export accounts for 90 per-cent of total export and the oil industry has little linkage with the Nigerian economy. Evidence has shown that it is the export of value added goods that help in diffusing foreign technology from developed countries to developing countries, and since Nigeria exports are dominated by primary products trade openness might therefore stunts the expansion of output per person. The above result also confirms previous results for Nigeria (see Olomola, 1998; Ekpo, 1990).

Also education was expected to impact positively on the growth of per capita income, this result however showed an insignificant relationship between economic growth and education. The reason for this might be the choice of proxy used which is secondary enrolment. This proxy has been identified as a flow in the education process and not a stock like, for example, education attainment (Solow, 2003). Another reason might have been the fact that education is used for non-productive activities for example, rent seeking. According to Pritchett (2001) massive expansion in education in African countries since the post-independence era of 1960s has not led to corresponding expansion in output because of the institutional environment that might result into perverse externalities from education. The study provides three main arguments for why education might not lead to expansion in output per capita. One, the marginal returnto education might be falling when demand for it is stagnant but the supply is growing. Two, institutional conditions might led to the use of education for socially wasteful activities, and three, poor quality of education might lead to schooling not producing any human capital. Another argument was provided by Sedgley (1998) who showed that what drive innovation might not be stock of human capital in the economy but the nature and the structure of human capital. The study showedthat the ratio of engineers and scientists totalgraduates, and a measure of innovative activity, proxy by the number of patents granted have positive impact on the expansion of income per worker across different states in the United States. This means that innovation and technological transfer are driven by the nature of human capital and not by its flow or stock.

Among the three other variables, investment, inflation and exchange rate, only investment return a negative coefficient and this is contrary to expectation, whereas inflation and exchange rates behaved as expected. The negative coefficient of inflation shows that a declining rate of inflation is good for the expansion of output per worker; while exchange rate depreciation is expected to result in expand income per capita. What is important from the above results is the while most cross-country studies have shown positive relationship for the impact of trade and education on growth for different categories of countries there is the need to consider individual country characteristics. It is therefore necessary to use country specific study to have a better understanding of those factors that drive this relationship. 


\section{Conclusion}

This paper examined how trade openness can drive economic growth in Nigeria working through technological progress adopted from more developed trading partners. The process of the absorption of these technologies and innovation can only be done by an educated workforce. The paper used the traditional measurement of trade openness, the ratio of the sum of total imports and total exports to GDP and gross secondary school enrolments as proxy for education. The core argument here is that technology diffusion remains one of the best channels through which international can be beneficial to developing countries. Other variables added were inflation rate, share of investment in GDP, and exchange rate. The paper specified an augmented version of the popular Solow model as popularised by Markiw, Romer, and Weil, (1992).

The findings of this study showed that trade openness may actually stunts the growth rate of income per capita in Nigeria, while this result does produce evidence for the welfare gains from trade liberalisation, it does show that the expected gain from opening up a developing economy to trade may be sensitive to both the structure of the economy and its trade structure. Nigeria still depends almost exclusively on crude oil exports for its exports earnings and its manufactured exports as share of total export is still negligible. It follows therefore that trade driven mainly by natural resource rents may not be growth enhancing. This finding has been supported by many previous findings.

Additionally, the impact of education on the economic growth is not significant for Nigeria data and this may not be surprising for two reasons. One the proxy used, gross secondary school enrolments represent a flow in the education process whereas the stock of educated labour force which might have been capture by education attainment may have been better but access to such data has been a challenge especially for Nigeria. Two, the quality of education might have been so poor that the positive externalities expected from education might have been difficult to achieve. These two results indicate that policy makers in Nigeria need to pay more attention to changing the structure of Nigeria export through diversification, while at the same time reform the education system to make it more demand driven. This study has also thrown up a challenge for future study in exploring whether a more definite measure of innovation and technology diffusion like numbers of patents granted can provide better insight into how human capital drives economic growth.

\section{References}

[1] African Development Bank(2015). Selected Statistics for African Countries. Abidjan Cote d'voire, African Development Bank.

[2] Akinlo,A.E.(2003). Foreign direct investment and economic growth in sub-Saharan Africa.International Review of Economics and Business, 50(4): 569-80

[3] Arodoye, N.L. And Iyoha, M.A (2014). Foreign trade-economic growth nexus: Evidence From Nigeria. CBN Journal of Applied Statistics, 5(1), 121-141.

[4] Attanasio, O., Goldberg.,P., and Pavenik., N. (2004). Trade reforms and wage inequality in Colombia, Journal of Development Economics 74, 331-336.

[5] Barro, R.(1991). Economic growth in a cross-section of countries.The Quarterly Journal of Economics, 106, 2 May pp 407-43.

[6] Benhabib, j and Spiegel. M.(2003).Human capital and technology diffusion. Working Paper in Applied Economic Activity Theory, 2003-02.Federal Reserve Bank of San Francisco.

[7] Busse, M., and Koniger J.,(2012) Trade and economic growth: A re-examination of the empirical evidence. Hamburg Institute of International Economics Paper 123. Hamburg.

[8] Central Bank of Nigeria (2014) Statistical Bulletin, vol, 25, December, Abuja, Central Bank of Nigeria.

[9] Chen,P.P. and Gupta.,R.(2006). An empirical investigation of openness and economic growth using panel estimation.Working Paper 2006-22.

[10] Collier, Paul and Roberts A Bates (2007) Endogenizing Syndromes In BennoNdulu, Stephen A. O’Connell, Robert H. Bates, Paul Collier and Chukwuma C. Soludo eds. The Political Economy of Economic Growth in Africa 1960-2000 Vol 1.Cambridge; Cambridge University Press.

[11] Dollar, D.,(1992). Outward-oriented developing economies do grow more rapidly: evidence from 95 LDCs, 1976-1985. Economic Development and Cultural Change. 40, 523-544.

[12] Edward, S.(1997). Trade policy, growth and income distribution.America Economic Review, 87(2), 205-210

[13] Ekpo, A.H. \&Egwakhide, F.(1994). Export and economic growth n Nigeria.A reconsideration of evidence. Journal of Economic Management.(1)1, 100-18.

[14] Ekpo, A.H.(1995). Openness and economic performance in Nigeria: A time series approach. Selected Papers for 1995 Annual Conference.The Nigerian Economic Society.

[15] Fosu, A.K.,(1990a). Exports and economic growth: the African case. World Development 18(6), 831-835.

[16] Fosu, A.K.,(1990b). Exports composition and the impact of exports on economic growth of developing countries.Economics Letter.34(1).

[17] Goff., M.F. and Sigh R.S.(2014). Does trade reduce poverty? A view from Africa.Journal of African Trade 1(2014) 5-14.

[18] Grossman G.M. and Helpman. E.,(1991). Innovation and Growth in the Global Economy.MIT Press.Cambridge MA and London.

[19] Harrisson A.,(1996). Openness and growth: a time series, cross country analysis for developing countries. Journal of Development Economics 59, 125-154.

[20] Lucas, R.E. (1988), On the mechanics of economic development. Journal of Monetary Economics, 22(1), 3-42.

[21] Mankiw., W.G., Romer., D., and Weil., D.N.(1992). A contribution to the empirics of economic growth.Quartely Journal of Economics, 107(2), 407-437.

[22] National Bureau of Statistics (2010), Nigeria Poverty Profile 2010. Abuja, Nigeria. National Bureau of Statistics.

[23] Nowak-Lehman D.F.(2000). Trade Policy and its Impact on Economic Growth. Can Openness Speed Up Output Growth? GeorgAugust-Universistat Gottingen, Ibero-America Institute for Economic Research (IAI). Gottingen. 
[24] Obadan., M. and Elizabeth., I.O.(2010). Empirical analysis of the impact of trade on economic growth in Nigeria. Jos Journal of Economics. 4(1), 1-23.

[25] Oladapo, O.S.(1998). Trade globalisation and economic growth in Nigeria.1960-1998. Ife Social Science Review, 15(1); 80-92.

[26] Olomola, P.A.(1998). Openness and log-run economic growth in Nigeria, 1960-1998, Journal of Economic Management, 5(1)

[27] Onafowora,O.A.andOwoye,O(1998). Can trade liberalisation stimulates economic growth in Africa.?World Development. 26(3), 497-506.

[28] Pritchett, L.(2001). Where has all the education gone?.World Bank Economic Review. 15(3)

[29] Romer, P.A.(1990). Endogenous technological change. Journal of Political Economy.98

[30] Romer, P.M. (1986). Increasing returns and long -run growth. Journal of Economy, 95(5), 1002-1037

[31] Sach. J. and Warner, A.(1995) Economic reform and the process of global integration .Brooking Paper of Economic Activity.vol1, pp1-95.

[32] Sala-i-Martins X.(1994). Economic growth, cross-sectional regressions and the empirics of economic growth.European Journal of Economic Review, 38, pp, 739-47.

[33] Sedgley. N .(1998). Technology gaps, economic growth and convergence across states. Applied Economic Letters 5 pp55-9.

[34] Solow, R.M. (1956). A contribution to the theory of economic growth, Quarterly Journal Of Economics, $70(1), 65$.

[35] Solow, R.M.(2003). Growth empirics across countries. World Bank Economic Review.19(2).

[36] Winters, A., McCulloch, N and Mckay, A.(2004). Trade liberalisation and poverty: the evidence so far. Journal of Economic Literature XLII, 72-115.

[37] World Bank (2015), World Development Indicators. Washington DC. World Bank. 